\title{
Evaluating the Potential of Rice Straw as a Co-digestion Feedstock for Biogas Production in Bangladesh
}

\author{
Khondokar M. Rahman ${ }^{1, *}$, David Fulford ${ }^{2}$ and Lynsey Melville ${ }^{1}$ \\ ${ }^{1}$ Centre for Resilient Environments, School of Engineering and the Built Environment, Birmingham City \\ University, Millennium Point, Curzon Street, Birmingham, UK \\ ${ }^{2}$ Director, Kingdom Bioenergy Ltd, Reading, UK
}

\begin{abstract}
This research was done to evaluate the potential energy yield capacity of rice straw for anaerobic digestion (AD) as an alternative use of this material. Cattle markets were found to be a potential source that generates a significant amount of a mixture of $80 \%$ straw $+20 \%$ cattle dung. This waste rice straw/dung mix from cattle markets provides a good mixture with a much better $\mathrm{C} / \mathrm{N}$ ratio than pure straw. This mix of straw and dung are often left in piles in the market for between 10 and 20 days, where they degrade naturally. Tests involving feeding this mixture into a domestic biogas plant showed that the biogas yield is $0.099 \mathrm{~m}^{3} / \mathrm{kg}$ feed stock with a methane content of $74.43 \%$. . In the whole of Bangladesh there are 500 cattle markets, so their waste can produce about $35,000,000 \mathrm{MJ}$ of energy through AD. A biogas plant will continue to generate biogas, even after daily feeding has been stopped, although the gas production and the methane content do reduce with time.
\end{abstract}

Keywords: Anaerobic digestion, Biogas, Bangladesh, Feedstock, Rice straw.

\section{INTRODUCTION}

Rice is primarily grown in tropical and sub-tropical climates which are located in Southern and SouthEastern Asia: China, India, Indonesia, Bangladesh, and Vietnam. Over 90 percent of the world's rice is produced and consumed in the Asia-Pacific Region [1]. As a major producer and exporter of rice in the world, China reportedly produces around 204.28 million tonnes of rice per year. This is followed by India (152.60 million tonnes), Indonesia (69.04 million tonnes) and Bangladesh (34.45 million tonne). China is the largest global producer of rice straw [2]. Typically, information on rice production is used to estimate the amount of straw derived. According to Binod [3], the ratio of grain harvested and straw is $1: 1.5 \mathrm{~kg}$. This ratio would give around 650-975 million tons of rice straw per year globally. The proper management of this enormous amount of straw could enable it to be a potential biomass feedstock for anaerobic digestion (AD). Anaerobic digestion is a biochemical conversation of suitable biomass feedstock in the absence of oxygen which produces biogas and digestate. Biogas is a mixture of gases, composed of 50 to $70 \%$ of Methane $\left(\mathrm{CH}_{4}\right), 30$ to $40 \%$ of Carbon dioxide $\left(\mathrm{CO}_{2}\right)$, with small amounts of Hydrogen Sulphide $-\mathrm{H}_{2} \mathrm{~S}$ and can be used as a source of energy and the digestate can be used as a nutrient rich

\footnotetext{
Address correspondence to this author at the Centre for Resilient Environments, School of Engineering and the Built Environment, Birmingham City University, Millennium Point, Curzon Street, Birmingham, UK;

Tel: +44 (0)121331 5000; Fax: +44 (0)121331 5401;

E-mail: khondokar.rahman@bcu.ac.uk
}

fertilizer. A review of the traditional use of rice straw demonstrates that it is neither environmentally nor economically cost effective. This study assessed the potential use of rice straw as a potential feedstock for $A D$, based on some initial experiments.

\subsection{Traditional use of Rice Straw}

Traditionally, straw is managed through burning it on local farms. It is left in the fields and stacked in specific area and then some of it is used by households for domestic cooking and heating [4]. Since rice is largely produced in developing countries, some of the rice straw is also used for other traditional purposes, such as an animal feed and animal bedding and as a building material for examples as roof thatching. Any unused straw is burnt in the fields, which produces air pollution which can be seen as haze. Rice paddy contributes to the emission of greenhouse gases (GHGs) such as carbon dioxide, methane and nitrous oxide [5]. Burning a ton of straw will reportedly produce $3 \mathrm{~kg}$ of particulate matter, $60 \mathrm{~kg}$ of carbon monoxide, $1460 \mathrm{~kg}$ of carbon dioxide, $199 \mathrm{~kg}$ of dust and $2 \mathrm{~kg}$ of sulphur dioxide [6, 7]. These gases play an important role in affecting the atmosphere and environment that lead to global climate change [7]. Also, airborne particles can also easily invade the lungs causing respiratory disease, especially for children and patients with asthma. Furthermore, incomplete combustion produces carbon monoxide and carcinogenic hydrocarbons which could cause cancer [8]. Unburnt straw left in the fields can rot down, which leads to other environmental problems such as the emission of 
methane which is a major contributor to greenhouse gases, sharing around $80 \%$ of the total GHG emissions from the cultivation of crops $[4,9,10]$.

\subsection{Alternative use of Rice Straw}

To overcome the open burning of rice straw, more environmentally friendly waste management approaches could be introduced, leading to zero waste and zero burning. These approaches aim to re-use and recycle farm residues using aerobic composting or through anaerobic digestion. The biochemical composition of rice straw has a typical lignocellulosic composition: containing on average $30-45 \%$ cellulose, $20-25 \%$ hemicellulose, $15-20 \%$ lignin, and a number of minor organic compounds. Rice straw is poor in nitrogen, but relatively high in other inorganic elements such as silica, which forms an ash when burnt. The composition of rice straw offers a challenge with regard to applications for bioenergy purposes. The high carbon-to-nitrogen content of rice straw leads to a very low bio-degradability in comparison to other agricultural residues. This is of particular importance when straw is used as a feed material for anaerobic digestion to produce biogas. This means that straw needs to be blended with other agricultural residues, in order to speed up the degradation of organic constituents. In order to use rice straw for anaerobic digestion, it can be mix with animal manure.

For example, there are around 500 cattle markets in Bangladesh and the staple food for the cattle held in market pens is rice straw. Cattle market waste therefore contains mainly rice straw $(80 \%)$ mixed with cattle dung (20\%). This mixture is much easier for bacteria to decompose [11]. Cattle market rice straw could therefore be a potential $A D$ feedstock for many Asian countries.

There are some differences between cattle market wastes and the conventional feedstocks used for anaerobic digestion, such as animal and poultry dung. Cattle market waste has a much higher $\mathrm{C} / \mathrm{N}$ ratio than these feed materials. The Nitrogen present in a feedstock has two main effects:

(a) It provides an essential element for synthesis of amino acids, proteins and nucleic acids; and

(b) It is converted to ammonia which, as a strong base, neutralizes the volatile acids produced by fermentative bacteria.
It thus helps maintain the neutral $\mathrm{pH}$ conditions essential for cell growth. However, an overabundance of nitrogen in the substrate can lead to excessive ammonia formation, resulting in toxic effects [12]. It is therefore important that the amount of nitrogen in the feedstock is controlled, to avoid either nutrient limitation (too little nitrogen) or ammonia toxicity (too much nitrogen). The composition of the organic matter added to a digestion system has an important role on the growth rate of the anaerobic bacteria and the production of biogas.

There are several methods by which straw can be used to generate energy. Straw can be burnt in boilers to generate steam, which is used in turbines to generate electricity. Straw can be pre-treated to increase its biodegradability, which allows it to be used in the production of liquid biofuels, such as bioethanol, by fermentation. Most of these pre-treatment processes are too expensive to use for straw that is to be added to biogas plants. Less costly pre-treatment processes would enable the addition of straw in biogas plants to be used more widely.

Small farmers in Bangladesh often lack an understanding of how straw could be used to offer further benefits and further their socio-economic development. A survey of a number of respondents in the study area showed only a few were aware of the potential of using straw as an alternative energy source. Only $10 \%$ of the people surveyed knew that straw could be used as biofuel, by burning it in boilers to generate electricity (6.3\%). Even fewer knew it could be added to biogas plants (1.3\%). Another survey in Sekinchan showed that none of the respondents knew that straw has the potential to be developed as a renewable energy source [13].

\section{METHODOLOGY}

The assessment of the potential for using straw-rich cattle marking wastes involved a survey of a cattle market in Gazipur district on the amount of feed material available and also some initial tests on feeding this waste material into a biogas plant. The results of these investigations were scaled up to determine countrywide $A D$ energy capacity in two categories.

In the pilot trial, straw was collected from the cattle market and chopped to small pieces $(25-50 \mathrm{~mm})$. The biogas plant into which the straw and dung was fed was an existing domestic plant of nominal size $2 \mathrm{~m}^{3}$ (based on the assumed biogas yield capacity). The 
plant was of a fixed brick dome design that is built in good numbers across Bangladesh. The rice straw had been left in a heap in the market for 15 days, so had already started to break down.

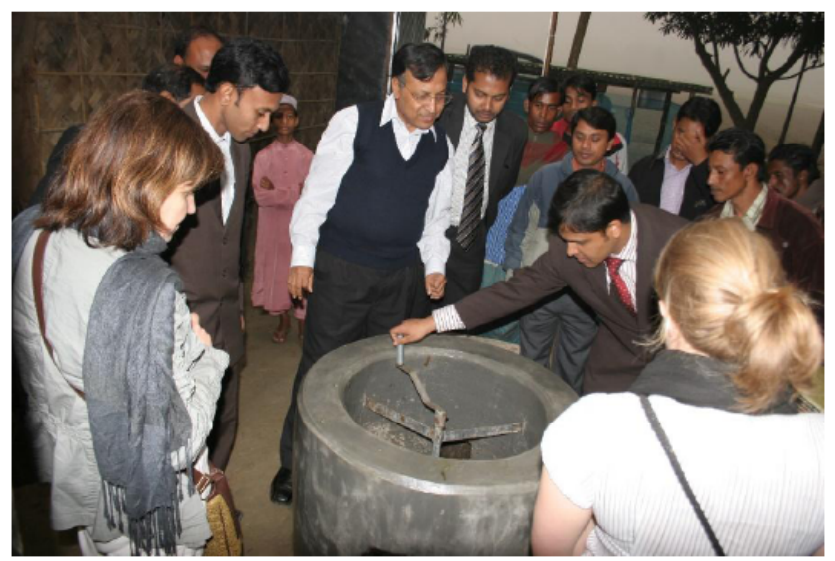

Figure 1: Feeding rice straw in a domestic experimental biogas plant.

The biogas plant into which the dung and straw were added and been used previously and some residual slurry remained at the bottom. The previous tests had used dung as feedstock. The remaining slurry was removed and an initial charge of straw, water and effluent slurry from another biogas plant was added. . This initial charge had a total wet mass of $1,300 \mathrm{~kg}$ of which $900 \mathrm{~kg}$ was old dung slurry plus $400 \mathrm{~kg}$ of rice straw. To give a total solids content of $8 \%, 1,600$ litres of water was also added, giving a total charge of 2,900 $\mathrm{kg}$ mixed slurry. The biogas plant was then fed daily with an $18 \mathrm{~kg}$ of a mix of straw and dung (as it came from the market) mixed 1:4 with water giving a daily charge of $90 \mathrm{~kg}$ (as shown in Table 1).

The biogas plant was fed daily with dung for 15 days after the initial charge. The daily feed was then stopped, as cattle markets occur periodically, so feed material is not always available.
Table 1: Daily and Initial Feedstock Loading Rate of Experimental Rice Straw Biogas Plant

\begin{tabular}{|c|c|c|}
\hline Charge & Feedstock & Amount (kg) \\
\hline Initial charge & Old slurry & 900 \\
\hline & Rice straw & 400 \\
\hline Total & Water & 1600 \\
\hline Daily charge & Rice straw/dung mix & $\mathbf{2 9 0 0}$ \\
\hline & Water & 72 \\
\hline Total & & $\mathbf{9 0}$ \\
\hline $\begin{array}{c}\text { Daily feedstock } \\
\text { application }\end{array}$ & & $\mathbf{1 5}$ days \\
\hline
\end{tabular}

The biogas composition was measured after 3 different durations (10, 15 and 30 days) following the first feeding. The biogas composition gives an idea of how the anaerobic microbes respond to the feed materials. The total volume of the biogas and its composition were determined with the help of the analytical laboratory of the Bangladesh Council of Scientific and Industrial Research (BCSIR).

\subsection{Determination of Biogas Yield}

The biogas yields were determined by using a portable gas flow meter from BCSIR. The flow meter shown in Figure 2 (left) was made in Germany by Ritter.

The biogas yield was measured using two methods. An underground biogas plant is able to store gas using the displacement principle, in which slurry is pushed into a reservoir by gas pressure. In the first method, the plant was allowed to produce and store gas for 24 hours. Then the gas was released into a gas balloon through the gas meter. When the gas flow slowed
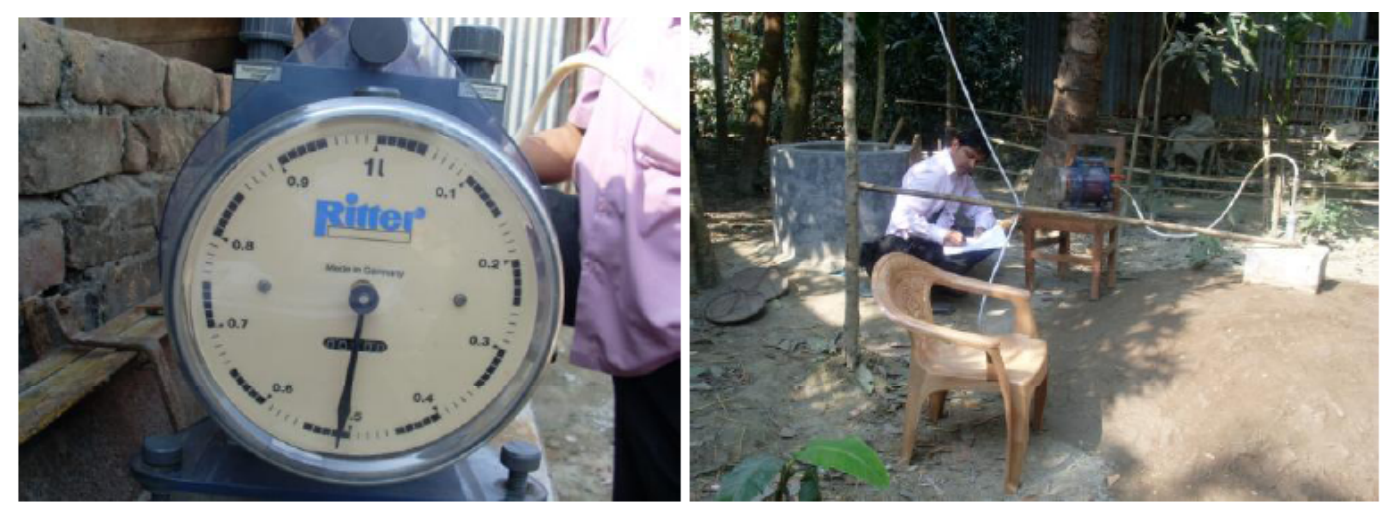

Figure 2: The digital flow meter is used to measure the biogas yield at a test site. 

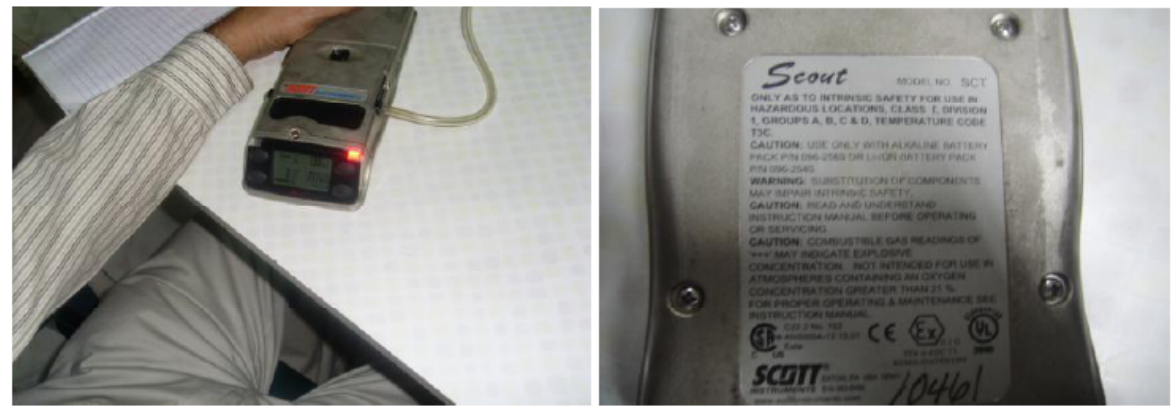

Figure 3: The digital gas analyser is used for biogas analysis at BCSIR's laboratory.

down to a slow steady rate (from the activity of the microbes), the reading of the total gas measured was taken, giving a figure of the total gas produced over the previous 24 hours.

The second approach was to measure the steady gas flow from the activity of the microbes, without gas storage. The gas flow reading was taken over 30 minute intervals for 3 hours and 6 measurements were recorded in each interval. The average value was calculated and it was found that the variation in gas flow was minimal. From these readings, a daily gas production value was calculated. A brief description of this process is shown in Table 2.

Table 2: Methods of Data Collection from a Biogas Plant, During Biogas Flow in Steady State, to Determine Biogas Yield

\begin{tabular}{|c|l|c|}
\hline & \multicolumn{1}{|c|}{ Action } & Remarks \\
\hline \hline 1 & Total duration measured flow rate & 3 hours \\
\hline 2 & Flow rate reading interval & $\begin{array}{c}\text { Every } 30 \text { minutes } \\
(7 \text { times })\end{array}$ \\
\hline 3 & Number of readings taken every interval & 6 \\
\hline 4 & Total readings during 3 hours & 42 \\
\hline 5 & Measured biogas yield & Litre/day \\
\hline
\end{tabular}

\subsection{Determine Biogas Composition}

Gas samples were taken twice a day for three days. The biogas samples were collected in gas balloons and were taken to BCSIR's laboratories in Dhaka for analysis. The laboratory had the capacity to determine the methane content and biogas yield. A laboratory scientist from BCSIR assisted with the analysis. The amount of $\mathrm{H}_{2} \mathrm{~S}$ and $\mathrm{CO}$ was determined by using a digital gas analyser.

The volume percentage of methane and carbon dioxide was determined by using an Orsat gas analyser. Methane was determined by subtraction of the known amounts of $\mathrm{CO}_{2}, \mathrm{H}_{2} \mathrm{~S}$ and $\mathrm{CO}$ from the gas sample. The Orsat equipment used to determine biogas compositions are shown in Figure 4. The measurements were used to determine the ratio of methane to carbon dioxide.

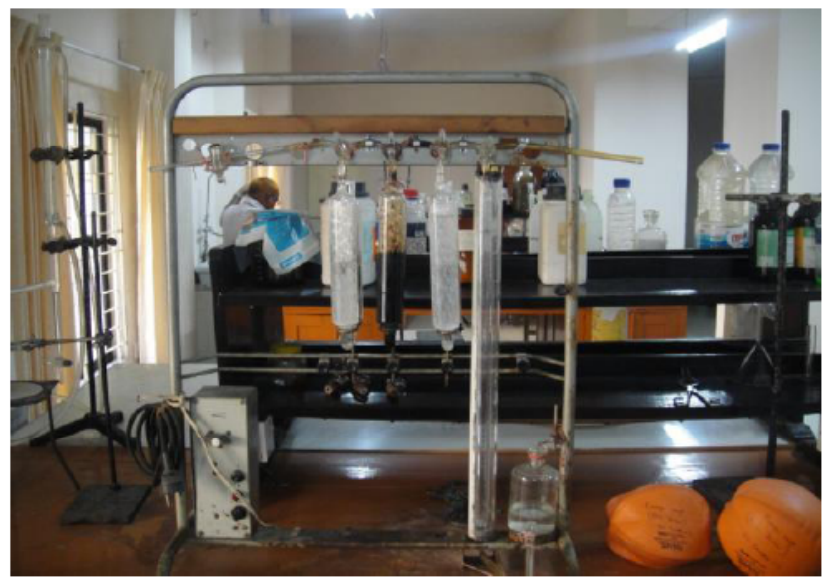

Figure 4: Orsat gas analyser is ready to analyse $\mathrm{CH}_{4}$ and $\mathrm{CO}_{2}$

\section{RESULTS AND DISCUSSION}

The results of the initial test using a biogas plant can be used to suggest the wider potential of using cattle market wastes to feed biogas plants in Bangladesh, by scaling up the information gained in this one market. . Cattle market waste is taken as a mixture of $80 \%$ rice straw $80 \%$ straw and $20 \%$ dung as found in this cattle market. It is assumed that one animal in a market can provide $35 \mathrm{~kg}$ of rice straw/dung waste daily. The energy attributes of waste rice straw/dung feedstock are shown in Table 3.

\subsection{Interaction of Bacteria with Feedstock}

The daily charge was fed into the digester for up for 15 days after the initial charge. After the $15^{\text {th }}$ day the daily charge was stopped. The biogas composition was measured on the $10^{\text {th }}$ day, $15^{\text {th }}$ day and $30^{\text {th }}$ days. 
Table 3: Potential Energy Yield Capacity of Waste Rice Straw as an AD Feedstock

\begin{tabular}{|c|c|}
\hline Energy attributes & Values \\
\hline \hline Total Solid $(\%$ TS $)$ & 45.08 \\
\hline Biogas Yield $\left(\mathrm{m}^{3} / \mathrm{kg} \mathrm{FS}\right)$ & 0.099 \\
\hline$\%$ Methane & 74.43 \\
\hline
\end{tabular}

These results give a sense of the bacterial activity relating to the feedstock availability. The results are given in Table $\mathbf{5}$ and graphically represented in Figure 5.

Since the digester was started with active slurry, the microbes were able to generate a biogas with around $75 \%$ methane on the 10th and 15th days On the 30th day the methane percentage was reduced $(62.5 \%)$, as the microbes were not getting a daily feed.

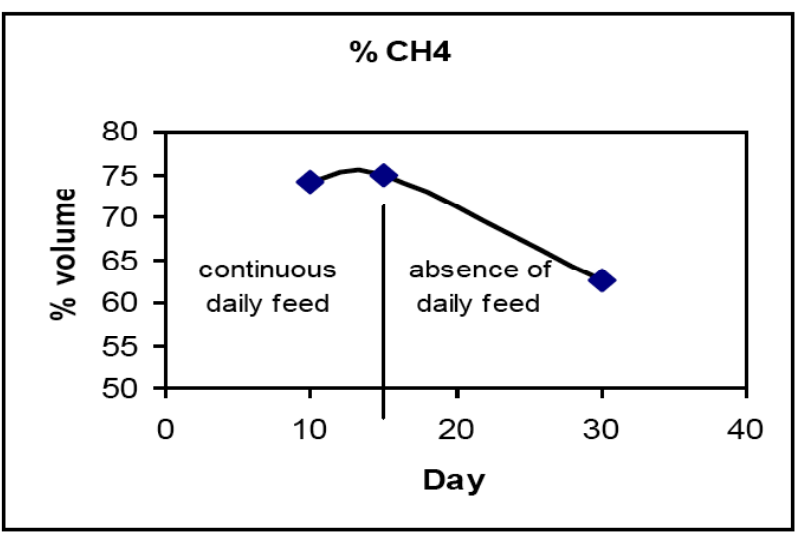

Figure 5: Percent methane on different days after charging.

For the reactor in the mesophilic range, the usual time of regeneration of the acedogenic anaerobic bacteria is 2 days; of clostridia 2 - 3 days; of the acetogenic bacteria 4 - 5 days; and the methanogenic microbes 5 - 16 days [14]. The absence of a daily charge causes impact on biogas and methane yield, due to the variation of bacterial activities inside the digester. After 10 days of feeding, the microbes are working well and generating methane. After the feeding has stopped, the microbial activity slows down as the reserve of substrate is used up. After 15 days without daily charge the methane yield is beginning to reduce.

Rice straws are lignocellulosic materials with a low bulk density and relatively high silica content. The main chemical components on a dry basis are cellulose, hemicelluloses, lignin and ash. Lignin is found in the middle lamella and adjacent primary cell walls of the residue tissue, and as such it encapsulates the cellulose and hemicellulose fractions found primarily in the secondary cell walls. Rice straws have relatively high proportions of silica-rich ash. In order to use the biomass resource in rice straw, there is a need to pretreat it to increase biodegradability. For example, researchers in China have developed a solid-state sodium hydroxide $(\mathrm{NaOH})$ pretreatment process that can boost the production of biogas from rice straw by almost $65 \%$ by increasing its biodegradability [15]. Leaving the rice straw in a pile in the market allowed it to begin to rot, which acted as a form of pre-treatment. Allowing it to degrade in the biogas plant more easily.

\subsection{Energy Potential from Rice Straw (From Cattle Market Waste Straw)}

At the time these tests were done, there were 30 cattle markets in Gazipur and around 500 cattle markets in Bangladesh. The study divided the cattle markets into two categories, according to biogas yield capacity. A market that held an average number of cattle of 390 or more was categorised as large and while that with 1,150 or more was considered as extralarge. A survey of local cattle markets showed that the average number of cattle number in the large markets is 390 and they produce a huge amount of rice straw/dung feedstock. The size of biogas plant required to process this amount is feed material is much larger than a domestic sized plant. It is calculated that a biogas plant to process material from a large market

Table 4: Scale up of Cattle Market Rice Straw Sector Energy Pattern of Bangladesh

\begin{tabular}{|c|c|c|c|}
\hline & Gazipur & Bangladesh & AD Capacity ( ${ }^{3}$ Biogas) \\
\hline \hline Number of cattle market & 30 & 500 & 0 \\
\hline Total Energy (MJ) & $2,098,430$ & $34,973,819$ & 1350 \\
\hline Domestic size & 0 & 0 & 4000 \\
\hline Large (1000-2000 $\mathrm{m}^{3}$ biogas) & 16 & 265 & $\mathbf{5 3 5 0}$ \\
\hline Very Large (1000-2000 $\mathrm{m}^{3}$ biogas) & 14 & $\mathbf{5 0 0}$ & \\
\hline Total & $\mathbf{3 0}$ & & \\
\hline
\end{tabular}


Table 5: Biogas Composition (\% by Volume) of Cattle Market Rice Straw Showed in Different Days After Charging

\begin{tabular}{|c|c|c|c|}
\hline Biogas & 10 days & 15 days & 30 days \\
\hline \hline $\mathrm{CH}_{4}$ & $74.18 \%$ & $74.92 \%$ & $62.50 \%$ \\
\hline $\mathrm{CO}_{2}$ & $25.82 \%$ & $25.08 \%$ & $37.20 \%$ \\
\hline $\mathrm{H}_{2} \mathrm{~S}$ & $0.00 \%$ & $0 \%$ & $0 \%$ \\
\hline $\mathrm{CO}$ & $0.00 \%$ & $0.0005 \%$ & $0.004 \%$ \\
\hline $\mathrm{O}_{2}$ & $0.00 \%$ & $0 \%$ & $0.30 \%$ \\
\hline
\end{tabular}

would need a capacity to produce $1,350 \mathrm{~m}^{3}$ of biogas daily, while that for an extra-large market to produce $4,000 \mathrm{~m}^{3}$ of biogas daily. In the whole of Bangladesh using the figure of 500 cattle markets suggests their waste can produce about $35,000,000 \mathrm{MJ}$ of energy if it is fed to $A D$ systems, with an average $A D$ capacity from each cattle market of $70,000 \mathrm{MJ}$.

The potential biogas energy from cattle market rice straw in Bangladesh of $35 \times 10^{6} \mathrm{MJ}(35 \mathrm{TJ})$ is equivalent to $35 \times 10^{6} \times 0.2778 \mathrm{kWh}$ or $9.723 \times 10^{9} \mathrm{Wh}$. So the energy that could be generated from feeding $A D$ plants with rice straw/cattle dung wastes is significant. This amount of energy could meet the energy requirement of a substantial number of people, especially if it is used to fuel engines to generate electricity. It is also feasible to use this energy for small to medium industrial needs. Generally the cattle markets take place in rural and more remote urban areas of Bangladesh. Therefore this energy can play a vital role for the rural community.

It has been observed globally that renewable energy technologies are economically viable for distant rural electrification programs which upgrade the living standards of the rural people. The majority of energystarved households are located in rural areas $[16,17]$. A large portion of the remote areas are not likely to be covered by the grid network due to inaccessibility and low customer density. Cattle market based biogas technologies could be considered viable alternatives for remote off-grid areas. The impact of the rural electrification in Bangladesh will be very large especially in the health care, education, family planning as well as female development and employment.

\subsection{Feedstock Composition and Pretreatment}

Biomass, such as straw is composed of lignin, cellulose, hemicellulose and other food materials. Anaerobic digestion can degrade most of these materials, apart from lignin, although cellulose takes several weeks. Hemicellulose, fat, and protein will break down in a few days. Low molecular sugars, volatile fatty acids and alcohols exhibit degradation rates as short as a few hours. Basically lignin is not digested in the anaerobic conditions in a biogas plant.

Ruminants degrade biomass materials to release energy, so use the more digestible components first. This means that their dung also contains mostly lignin and that is why dung yields so little biogas. The process of hydrolysis converts materials such as $16.4 \%$ cellulose, $36.8 \%$ hemicellulose, and $28.4 \%$ lignin, into water-soluble substances, which were increased by $122.5 \%$ [18]. This research showed that the ester bond of lignin-carbohydrate complexes (LCCs) was broken by the hydrolysis reaction, releasing more cellulose for biogas production. The linkages of inter-linking units and the functional groups of lignin, cellulose, and hemicellulose were either broken or destroyed, leading to significant changes in chemical structures. The original lignin with a large molecular weight and threedimensional network structure was broken into components with a small molecular weight and linear structure after $\mathrm{NaOH}$ pre-treatment [15]. The cellulosic crystal style was not obviously changed, but the crystallinity of cellulose increased. The changes of chemical compositions, chemical structures and physical characteristics made rice straw more biodegradable and thus responsible for enhancement of the biogas yield. In another study it was found that pre-treatment of rice straws reduced the retention time in the anaerobic digestion process [19]. Ruihong Zhang and Zhiqin Zhang investigated the effects of different pretreatment methods, physical (mechanical), thermal and chemical (ammonia) treatment, on the digestion of rice straw at the mesophilic temperature of $35^{\circ} \mathrm{C}$. A combination of grinding (10-mm length), heating $\left(110^{\circ} \mathrm{C}\right)$, and ammonia treatment $(2 \%)$ resulted in the highest biogas yield, 0.47 I g-1 VS-1 fed, which is $17.5 \%$ higher than the biogas yield of untreated whole straw. Pre-treatment temperature has a significant effect on the digestibility of straw. These processes are costly, so there is a need for a low-cost pre-treatment process that is effective.

\section{C/N RATIO}

The $\mathrm{C} / \mathrm{N}$ ratio is a factor that affects biogas yield as it influences the $\mathrm{pH}$ value of the slurry. The optimum yield of biogas comes from a feed material with a range of $\mathrm{C} / \mathrm{N}$ ratio of 20 to $30: 1$. The use of straw for biogas production is restricted by its high $\mathrm{C} / \mathrm{N}$ ratio (87-90:1) and low levels of other, trace elements, which limit 
microbial growth and activity. The biogas yield from straw can be increased by pre-treatment, making the material more accessible to microbial degradation. The addition of materials such as Urea $\left(\mathrm{NH}_{2}-\mathrm{CO}-\mathrm{NH}_{2}\right)(46 \%$ $\mathrm{N})$, Ammonium hydroxide $\left(\mathrm{NH}_{4} \mathrm{OH}\right)(40 \% \quad \mathrm{~N})$ and Ammonia $\left(\mathrm{NH}_{3}\right)(83 \%)$ could be used for commercial biogas production from crop straw. Again, this adds cost to the process, so low cost additives need to be found. Co-digestion with more nitrogen-rich materials, for example, animal manure or food waste, allows the nutrient limitation can be overcome.

\section{CONCLUSION}

This study has demonstrated the need to make more effective use of rice straw as a source of energy and the use of $A D$ is one way in which this can be done. However, the character and composition of straw make it difficult to degrade. The mixing of nitrogen rich manure i.e. cow dung, with rice straw will increase the specific ability of the microbes in a biogas plant to use it. Pre-treatment is important for maximise biogas production. There are various techniques that can be used to pre-treat rice straw, but these are expensive. There is a need to develop a low cost approach to pretreatment of materials such as rice straw.

\section{REFERENCES}

[1] Papademetriou MK. Rice production in the Asia-Pacific Region: Issues and perspectives. In 'Bridging the Rice Yield Gap in the Asia-Pacific Region'. FAO, UN, Bangkok, Thailand. RAP Publication 2000/16.

[2] Food and Agriculture Organization (FAO), 2014), Available from: http://faostat.fao.org.

[3] Binod P, Sindhu R, Singhania RR, Vikram S, Devi L, Nagalakshmi $S$ et al. Bioethanol production from rice straw: An overview. Bioresource Technology 2010; 101: 47674774.

https://doi.org/10.1016/j.biortech.2009.10.079

[4] Silalertruksa T, Gheewala SH. A comparative LCA of rice straw utilization for fuels and fertilizer in Thailand. Bioresource Technology 2013; 150: 412-419. https://doi.org/10.1016/j.biortech.2013.09.015

[5] Bhattacharya A. Carbon dioxide drove climate change during longest interglacial, Eos Trans. AGU 2012; 93(37): 360. https://doi.org/10.1029/2012E0370008

[6] Indian Agricultural Research Institute, 2012, Crop residues management with conservation agriculture: Potential, constraints and policy needs. Indian Agricultural Research Institute, New Delhi.

[7] Gupta RK, Garg SC. Residue burning in rice-wheat cropping system: Causes and implications. Current Science 2004; 87(12): 1713-1717.

[8] Henderick $\mathrm{P}$, Williams $\mathrm{RH}$. Trigeneration in a Northern Chinese village using crop residues. Energy for Sustainable Development 2000; 4 (3): 26-42.

https://doi.org/10.1016/S0973-0826(08)60251-3

[9] Mandal KG, Misra AK, Hati KM, Bandyopadhyay KK, Ghosh PK, Mohanty M. Rice residue: Management options and effects on soil properties and crop productivity. Food, Agriculture and Environment 2004; 2(1): 224-231.

[10] Dobermann A, Fairhurst TH, 2002, Rice straw management. Available from: http://www.ppi-ppic.org/ppiweb.

[11] Rahman KM, Woodard R, Manzanares E, Harder MK. Anassessment of anaerobic digestion capacity in Bangladesh. Renewable and Sustainable Energy Review 2014; 32: 762-9. https://doi.org/10.1016/j.rser.2014.01.026

[12] Ganiyu OT and Oloke JK. Effects of Organic Nitrogen and Carbon Supplementation on Biomethanation of Rice Bran, Fountain Journal of Natural and Applied Sciences 2012; 1(1): 25-30.

[13] Rosmiza MZ, Davies, WP, Rosniza Aznie CR, Mazdi M and Jabil MJ. Farmers' knowledge on potential uses of rice straw: An assessment in MADA and Sekinchan, Malaysia, GEOGRAFIA OnlineTM Malaysian Journal of Society and Space 2014; 10(5): 30- 43.

[14] Cooper C. Personal contact, Technical Director, Barfoot Energy Projects Ltd, Sefter Farm, Pagham Road, Bognor Regis, PO21 3PX 2010.

[15] Luo Qingming, Li Xiujin, C Zhu Baoning, Yang Dongyan and $\mathrm{Li}$ Laiqing. Anaerobic biogasification of $\mathrm{N}$ aOH treated corn stalk, Transactions of the CSAE 2005; 21(2): 111-115.

[16] Legros G, Havet I, Bruce $N$ and Bonjour S. The Energy Access Situation in Developing Countries: A Review Focusing on the Least Developed Countries and SubSaharan Africa. New York, USA: United Nations Development Programme (UNDP), World Health Organization 2009.

[17] World Bank. Designing Sustainable Off-Grid Rural Electrification Projects: Principles and Practices. Washington, DC: Energy and Mining Sector Board, The World Bank Group 2008.

[18] Yanfeng He, Yunzhi Pang, Yanping Liu, Xiujin Li and Kuisheng Wang. Physicochemical Characterization of Rice Straw Pretreated with Sodium Hydroxide in the Solid State for Enhancing Biogas Production, Energy \& Fuels 2008; 22 : 2775-2781. https://doi.org/10.1021/ef8000967

[19] Yuan Hairong, Yatian Zhang, Xiujin Li, Ying Meng, Chunmei Liu, Dexun Zou, Yanping Liu. Effects of Ammoniation Pretreatment at Low Moisture Content on Anaerobic Digestion Performance of Rice Straw, Bio Resources 2014; 9(4): 6707-6718

https://doi.org/10.15376/biores.9.4.6707-6718

Received on 20-03-2017 